\title{
エアクッション艇空気シール構造の 振動に関寸る研究
}

$\begin{array}{llllll}\text { 正員 今 } & \text { 井 兼 } & \text { 久* 永 } & \text { 園 秀 雄* } \\ \text { 正員 } & \text { 南 } & \text { 真 和* } & & \end{array}$

A Study on Vibration of the Pneumatic Seal Structure of the Air Cushion Craft

\author{
by Kanehisa Imai, Member
}

Hideo Nagasono,

Masakazu Minami, Member

\begin{abstract}
Summary
A fundamental study on vibration characteristics of the air cushion craft was performed taking dynamic behavior of the pneumatic seal structure into consideration.

A linearized mathematical model of the air cushion craft dynamics was derived. The effect of each parameter on the dynamic stability was obtained analytically and experimentally from the view point of negative resistance excitation system.

The conclusions are as follows:

1) The dynamic stability of pneumatic seal structural vibration depends on the air transmission line characteristics and the seal configuration. The effects of these parameters on the stability criteria of the system are numerically examined.

2) In the model test, the self excited vibration caused by the instability of the pneumatic seal system was observed in some range of the inlet area of fan and feedhole area in the air chamber.

3) The calculated fundamental natural frequency for air cushion craft model agreed very well with model test results. The stable region varied in accordance with feedhole area in the model test, and a similar tendencies were also observed in the numerical analysis.

A further study is necessary to discuss the difference between model test results and numerical analysis results.
\end{abstract}

\section{1 緒言}

エアクッション艇では, 地面の不整による強制振動の 他に空気流れによる自励的振動の発生が報告されてい

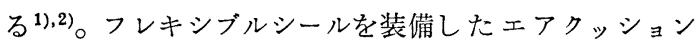
艇において報告されている特異な振動も後者に属するも のと考えられる。シール構造振動までを含めた理論的検 討例は少ないよらである。

エアクッション艇に考えられる振動問題を列挙してみ る。波浪中を走行するエアクッション艇の空気シール構 造は, 波面との接触あるいは空気室容積変化に伴う強 制変動力を受ける。したがって, 出会波周波数とシール 構造の固有振動数が一致する場合には, 動的な増幅を受 けて空気漏洩量変動を生じ，艇体振動を誘起する。ま た, 艇体, シール, 空気系で構成する振動系のパラメー

* 三井造船(株)技術開発本部千葉研究所
タの組み合せによっては，負性抵抗系としての不安定振 動発生の可能性がある。クッション室の容積変化やシー ル膜内張力の変化に伴なら見かけ剛性の変動による係数 励振振動も考学られる。

本研究は, それらの振動発生機構の解明と振動軽減手 法を確立するための基礎研究である。最初に, 既報文献 におけるシールに発生する振動問題の概要と, 導出した 振動系の線形モデルおよび振動系の動的安定性に影響を 及ぼすパラメータについて述べる。次に, 自励振動現象 に注目したエアクッション艇のモデル実験結果と理論計 算結果の比較を通して, 固有振動特性に及ぼすパラメー タの影響について考察する。

\section{2 シールの自励振動}

フレキシブルシールの採用により生じた自励的振動を 文献 1)，6）ではバウンスと称し，その現象的特徽を次 
のように述べている。“初期のバッグとフィンガーの構 成では, ある条件下で激しい自励的な振動を生じた。ス カート振動が，艇のヒーブ固有振動を励振する場合に特 に問題となる。振動は, 静水中の低速走行あるいはほと んどゼロの速度で生じており, リフトシステムのパワー を変える（例觉ば，ファンの回転数を変える）ことによ って解決できる場合もあるが，振動を止めるために停止 せざるを得ないこともある。”振動発生機構の定性的説 明として，以下のように述べている。“あし，シール高 さが変化すれば，シール下端クリアランスが変わり，ク ッションからの空気の流出流量に影響を与える。体積流 量は, バッグとクッション間の圧力差の平方根に比例す るため, シール高さが変化することは, これらの圧力が 変化することを意味する。これにより压力比が変化し, これに対応するようにシール形状, 高さが変化すること になる。”自励的振動の発生理由に対する説明は以上の 程度であり, 理論解析の具体的報告例は, 筆者らが調査 した限りでは見当らない。

文献 2) 中の大型モデルのテスト結果では, 振動サイ クル中の, バッグ圧, クッション圧の変動とフィンガー 下端の間隙の関係に, 次のような特徽的傾向が見られ る。

(1) クリアランスの増加時に圧力が低くなる位相差, つまり, 流量が増加する場合に圧力が低下する関係にな っている。

(2) クリアランスと压力変動現象の振動数比には,

$1: 1$ と $1: 2$ の成分が混在している。

安定領域の判定に関して, 次に示すようなバッグ压 $P_{b}$ とクッション压 $P_{c}$ の関係で求をる簡便な図が提案 されている。

(3) $P_{b}$ が $P_{c}$ よりる十分大きい範囲と $P_{b}$ が $P_{c}$ に ほぼ等しい領域に安定域がある。具体的には, $P_{b}$ と $P_{c}$ の比が, 約 $1.2 \sim 2.0$ の範囲を不安定域としている。

以上の報告より, 現象を推察してみる。文献 2) 中の 実験に見られたシール下端クリアランスと圧力の位相関 係は, シール構造の上下振動と流出流量変動が増幅的に なる関係を示している。それは，流体配管の管端に押し 開き型の弁を持つ振動系に見られる不安定振動成長のパ ターン 3) と共通点がある。不安定振動の成長によって圧 力変動を生ずれば, シール膜内にも張力変化を伴い, 係 数励振的な発振と係り合う可能性もある。不整面走行に よって変動外力を受ける場合も同様である。

\section{3 システムの線形化モデル}

ここでは，固有振動解析のための線形化モデルについ て述べる。Fig. 1 は概念的に示したシステムの全体構成 である。基礎実験との対比にも用いるため,ダクト系は

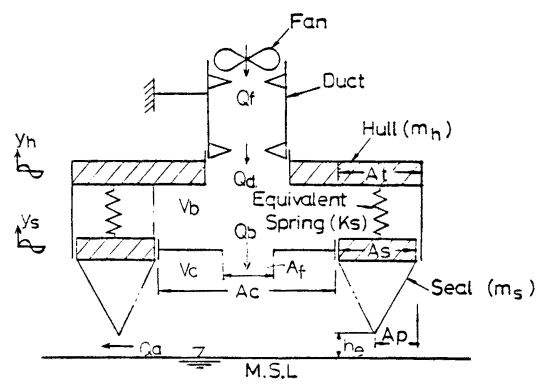

Fig. 1 Mathematical model for vibration analysis

分布定数系として気柱振動も含めるように配虑する。モ デルのシール部は, 概念的に示しているが, 本報ではバ ッグ・フィンガー様式を想定している。

\section{1 ファン・ダクト室のモデル化}

平衡状態からのファン送風空気変動圧力と変動流量の. 関係を次式で表わす。

$$
\Delta P_{f}=f^{\prime}\left(Q_{e}\right) \Delta Q_{f}
$$

ここで,

$$
\Delta P_{f}: \text { ファン送風空気変動圧力 }
$$

$\Delta Q_{f}:$ ファンの平衡状態風量 $Q_{e}$ からの変動流量

$f^{\prime}\left(Q_{e}\right)$ : 平衡状態流量 $Q_{e}$ におけるファン特性曲線の 傾き

フッン入ロの特性とダクト室下流端の状態量間の伝達 特性を次式で表わす4)。

$$
\left[\begin{array}{l}
\Delta P_{d} \\
\Delta Q_{d}
\end{array}\right]=\left[\begin{array}{c}
f^{\prime}\left(Q_{e}\right) \cosh \left(T_{e} s\right)-Z_{c} \sinh \left(T_{e} s\right) \\
-\frac{\left.f^{\prime}\left(Q_{e}\right)\right)}{Z_{c}} \sinh \left(T_{e} s\right)+\cosh \left(T_{e} s\right)
\end{array}\right] \cdot \Delta Q_{f}
$$

ここで,

$\Delta P_{d}:$ ダクト下流端変動圧力

$\Delta Q_{d}:$ バッグ室入口に括ける変動流量

$Z_{c}:$ ダクト室特性インピーダンス $\left(=\rho_{d} c / A_{d}\right)$

$$
T_{e}=l_{d} / c, s=\frac{d}{d t}
$$

$l_{d}, A_{d}:$ ダクト長さ, 断面積

$\rho_{d}, c:$ 空気密度, 空気中の音速

$T_{e} \rightarrow 0$ とすれば, $\Delta P_{d}=\Delta P_{f}, \Delta Q_{d}=\Delta Q_{f}$ となり, ダ クト室を無視できる。（3）式の近似のもとに（2）式 を書きかえると（4）式を得る。

$$
\begin{aligned}
& \left.\begin{array}{l}
\cosh \left(T_{e} s\right) \doteqdot 1+\frac{4}{\pi^{2}}\left(T_{e} s\right)^{2} \\
\sinh \left(T_{e} s\right) \fallingdotseq T_{e} s
\end{array}\right\} \\
& {\left[\begin{array}{l}
\Delta P_{d} \\
\Delta Q_{d}
\end{array}\right]=\left[\frac{a_{1} s^{2}+a_{2} s+f^{\prime}\left(Q_{e}\right)}{-b_{1} s^{2}+b_{2} s+1}\right] \cdot \Delta Q_{f}}
\end{aligned}
$$

ここで, 


$$
\begin{aligned}
& a_{1}=\frac{4}{\pi^{2}} f^{\prime}\left(Q_{e}\right) T_{e}^{2}, \quad a_{2}=-Z_{c} T_{e} \\
& b_{1}=\frac{4}{\pi^{2}} T_{e}^{2}, \quad b_{2}=-\frac{f^{\prime}\left(Q_{e}\right)}{Z_{e}} T_{e}
\end{aligned}
$$

3.2 バッグ室およびクッション室のモデル化

艇体, シールの変形に伴らバッグ室, クッション室の 容積 $V_{b}, V_{c}$ は次式で表わされる。

$$
\left.\begin{array}{l}
V_{b}=V_{b e}+A^{*} \cdot\left(y_{h}-y_{s}\right)-A_{a} y_{h} \\
V_{c}=V_{c e}+\left(A_{s}-A_{p}\right) y_{s}+A_{c} y_{h}
\end{array}\right\}
$$

ここで,

$V_{b e}, V_{c e}$ : 平衡状態でのバッグ室, クッション室容積 $A_{s} *$ : シールの有効受圧面積 $\left(=A_{s}(1+\beta)\right)$

$A_{\text {s }}$ : シールの基準受圧面積

$\beta$ : 形状係数

$A_{p}:$ シール前縁の受圧面積（投影面積）

$A_{c}$ : 艇下面の受圧面積

$y_{h}, y_{s}:$ 艇体, シールの変位

バッグ室, クッション室内の空気の挙動に関して断熱 変化を仮定すると,

$$
\begin{aligned}
&\left(P_{a}+\right.\left.P_{b e}\right) V_{b e^{r}} \\
&=\left(P_{a}+P_{b e}+\Delta P_{b}\right) \\
& \times\left\{V _ { b } \left(1-\frac{\Delta V_{d}}{V_{b e}+\Delta V_{d}-\Delta V_{b}}\right.\right. \\
&\left.\left.\left.+\frac{\Delta V_{b}}{V_{b e}+\Delta V_{a}-\Delta V_{b}}\right)\right\}^{\gamma}\right\} \\
&\left(P_{a}+\right.\left.P_{c e}\right) V_{c e^{\gamma}} \\
&=\left(P_{a}+P_{c e}+\Delta P_{c}\right) \\
& \times\left\{V _ { c } \left(1-\frac{\Delta V_{b}}{V_{c e}+\Delta V_{b}-\Delta V_{a}}\right.\right. \\
&\left.\left.+\frac{\Delta V_{a}}{V_{c e}+\Delta V_{b}-\Delta V_{a}}\right)\right\}^{\gamma}
\end{aligned}
$$

微小変形仮定のもとに次式が得られる。

$$
\begin{aligned}
\Delta P_{b}= & K_{b}\left\{\left(\Delta V_{d}-\Delta V_{b}\right)\right. \\
& \left.-A_{s} *\left(y_{h}-y_{s}\right)+A_{d} y_{h}\right\} \\
\Delta P_{c}= & K_{c}\left\{\left(\Delta V_{b}-\Delta V_{a}\right)\right. \\
& \left.-\left(A_{s}-A_{p}\right) y_{s}-A_{c} y_{h}\right\} \\
K_{b}= & \gamma\left(P_{d}+P_{b e}\right) / V_{b e} \\
K_{c}= & \gamma\left(P_{a}+P_{c e}\right) / V_{c e}
\end{aligned}
$$

ここで,

$P_{b e}, \Delta P_{b}:$ バッグ室平衡状態圧力, 変動圧力

$P_{c e}, \Delta P_{c}:$ クッション室平衡状態圧力, 変動圧力

$P_{a}:$ 大気圧

$\Delta V_{d}, \Delta V_{b}, \Delta V_{a}$ : バッグ室入口, クッション室入口,

シール下端出口を通過する空気の変動容積

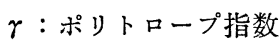

$K_{b}, K_{c}$ : バッグ室, クッション室の音響キャパシタ ンスの逆数

バッグ室入口, クッション室入口, シール下端出口部
の平衡状態からの変動流量, 変動圧力の関係に対し, 次 の線形化式を用いる。

$$
\left.\begin{array}{l}
\Delta Q_{d}=s \Delta V_{d}=\left(\Delta P_{d}-\Delta P_{b}\right) / R_{d} \\
\Delta Q_{b}=s \Delta V_{b}=\left(\Delta P_{b}-\Delta P_{c}\right) / R_{b} \\
\Delta Q_{a}=s \Delta V_{a}=\Delta P_{c} / R_{a}+y_{s} / \alpha_{a}
\end{array}\right\}
$$

ここで,

$$
\begin{aligned}
& R_{d}=2\left(P_{d e}-P_{b e}\right) / Q_{e} \\
& R_{b}=2\left(P_{b e}-P_{c e}\right) / Q_{e} \\
& R_{a}=2 P_{c e} / Q_{e} \\
& \alpha_{a}=h_{e} / Q_{e}
\end{aligned}
$$

$h_{e}$ : 平衡状態でのシール下端クリアランス

（8）式に，(4)，(7) 式を代入して変動圧力の項 $\Delta P_{d}$, $\Delta P_{b}, \Delta P_{c}$ を消去すると次式を得る。

$$
\begin{aligned}
& K_{b}\left(A_{s} *-A_{d}\right) y_{h}-K_{b} A_{s} * y_{s} \\
& \quad+\left(a_{1} s^{2}+a_{2} s+f^{\prime}\left(Q_{e}\right)\right) \Delta Q_{f} \\
& \quad-\left(R_{d} s+K_{b}\right) \Delta V_{d}+K_{b} \Delta V_{b}=0 \\
& \left\{K_{c} A_{c}-K_{b}\left(A_{s} *-A_{d}\right)\right\} y_{h} \\
& \quad+\left\{K_{c}\left(A_{s}-A_{p}\right) K_{b} A_{s} *\right\}+K_{b} \Delta V_{d} \\
& \quad-\left\{R_{b} s+\left(K+K_{c}\right)\right\} \Delta V_{b}+K_{c} \Delta V_{a}=0 \\
& \quad-K_{c} A_{c} y_{h}+\left\{\left(R_{a} / \alpha_{a}\right)\right. \\
& \left.\quad-K_{c}\left(A_{s}-A_{p}\right)\right\} y_{s} \\
& \quad+K_{c} \Delta V_{b}-\left(R_{a} s+K_{c}\right) \Delta V_{a}=0
\end{aligned}
$$

\section{3 艇体, シール系の運動方程式}

艇体およびシール系の運動方程式は次式で表わせる。

$$
\left.\begin{array}{rl}
-m_{h} \ddot{y}_{h}+A_{t} \Delta P_{b}+ & A_{c} \Delta P_{c} \\
- & k_{s}\left(y_{h}-y_{s}\right)=0 \\
-m_{s} \ddot{y}_{s}-A_{s} \Delta P_{b}+ & \left(A_{s}-A_{p}\right) \Delta P_{c} \\
+ & k_{s}\left(y_{h}-y_{s}\right)=0
\end{array}\right\}
$$

ここで,

$m_{h}:$ 艇体質量

$m_{s}:$ シールの有効振動質量

$k_{s}:$ シールの有効ばね定数

$A_{t}:$ 艇の上甲板の受圧面積

（11）式の両辺を初期值 0 としてラプラス変換し，これ に（7）式を代入すると,

$$
\begin{aligned}
\{ & -m_{h} s^{2}-K_{b} A_{t}\left(A_{s} *-A_{d}\right) \\
& \left.-K_{c} A_{c}{ }^{2}-k_{s}\right\} y_{h}+\left\{K_{b} A_{t} A_{s}{ }^{*}\right. \\
& \left.-K_{c} A_{c}\left(A_{s}-A_{p}\right)+k_{s}\right\} y_{s}+K_{b} A_{t} \Delta V_{d} \\
& +\left(-K_{b} A_{t}+K_{c} A_{c}\right) \Delta V_{b} \\
& -K_{c} A_{c} \Delta V_{a}=0 \\
\{ & K_{b} A_{s}\left(A_{s}{ }^{*}-A_{d}\right) \\
& \left.-K_{c} A_{c}\left(A_{s}-A_{p}\right)+k_{s}\right\} y_{h} \\
& +\left\{-m_{s} s^{2}-K_{b} A_{s} A_{s}^{*}\right. \\
& \left.-K_{c}\left(A_{s}-A_{p}\right)^{2}-k_{s}\right\} y_{s}-K_{b} A_{s} \Delta V_{d} \\
& +\left\{K_{b} A_{s}+K_{c}\left(A_{s}-A_{p}\right)\right\} \Delta V_{b} \\
& -K_{c}\left(A_{s}-A_{p}\right) \Delta V_{a}=0
\end{aligned}
$$




\begin{tabular}{|c|c|c|c|c|c|c|}
\hline $\begin{aligned} & -m_{h} s^{2} \\
- & K_{b} A_{t}\left(A_{s} *-A_{d}\right) \\
- & K_{c} A_{c}{ }^{2}-k_{s}\end{aligned}$ & $\begin{array}{l}K_{b} A_{t} A_{s} * \\
\quad-K_{c} A_{c}\left(A_{s}-A_{p}\right) \\
\quad+k_{s}\end{array}$ & 0 & $K_{b} A_{t}$ & $\begin{array}{l}-K_{b} A_{t} \\
+K_{c} A_{c}\end{array}$ & $-K_{c} A_{c}$ & $y_{h}$ \\
\hline $\begin{array}{l}K_{b} A_{s}\left(A_{s} *-A_{d}\right) \\
\quad-K_{c} A_{c}\left(A_{s}-A_{p}\right) \\
\quad+k_{s}\end{array}$ & $\begin{aligned} & -m_{s} s^{2} \\
- & K_{b} A_{s} A_{s} * \\
- & K_{c}\left(A_{s}-A_{p}\right)^{2}-k_{s}\end{aligned}$ & 0 & $-K_{b} A_{s}$ & $\begin{array}{l}K_{b} A_{s} \\
-K_{c} \\
\times\left(A_{s}-A_{p}\right)\end{array}$ & $\begin{array}{l}-K_{c} \\
\times\left(A_{s}-A_{p}\right)\end{array}$ & $y_{s}$ \\
\hline 0 & 0 & $\begin{array}{l}b_{1} s^{2} \\
+b_{2} s \\
+1\end{array}$ & $-s$ & 0 & 0 & $\Delta Q_{f}$ \\
\hline$K_{b}\left(A_{s} *-A_{d}\right)$ & $-K_{b} \cdot A_{s} *$ & $\begin{aligned} & a_{1} s^{2} \\
+ & a_{2} s \\
+ & f^{\prime}(Q)_{e}\end{aligned}$ & $\begin{array}{l}-R_{d} s \\
-K_{b}\end{array}$ & $K_{b}$ & 0 & $\Delta V_{d}$ \\
\hline $\begin{array}{l}-K_{b}\left(A_{s}^{*}-A_{d}\right) \\
\quad+K_{c} A_{c}\end{array}$ & $\begin{array}{l}K_{b} A_{s}^{*} \\
\quad+K_{c}\left(A_{s}-A_{p}\right)\end{array}$ & 0 & $K_{b}$ & $\begin{array}{l}-R_{b} s \\
-\left(K_{b}+K_{c}\right)\end{array}$ & $K_{c}$ & $\Delta V_{b}$ \\
\hline$-K_{\mathrm{c}} A_{c}$ & $\begin{array}{c}-K_{c}\left(A_{s}-A_{p}\right) \\
\quad+R_{a} / \alpha_{a}\end{array}$ & 0 & 0 & $K_{\mathrm{c}}$ & $\begin{array}{r}-R_{a} s \\
-K_{c}\end{array}$ & $\Delta V_{a}$ \\
\hline
\end{tabular}

\section{4 動 的 安 定 領 域}

（13）式の係数行列を 0 とする振動数方程式より複素 固有值を求め, 減衰係数の符号より振動系の安定性を判 別する。パラメータと振動系の動的安定性の関連の考察 を容易にするため, 自由度を縮約した非連成振動系の個 タについて検討する。非連成振動系の呼称を, $y_{h}=y_{s}$ としたものを艇体振動系， $y_{h}=0$ としたものをシール振 動系とする。ここでは，計算を簡単にするため， $T_{e}=0$, $A_{d}=0$ としてダクト影響を無視し, さらに, $A_{t}=A_{s}$, $A_{p}=0$ とした場合の系について考察する。

\section{1 艇体振動の安定領域}

$y_{h}=y_{s}$ として縮約した運動方程式の 係数行列式を0 と拉くと, 次の振動数方程式を得ることができる。

$$
s^{4}+A_{3} s^{3}+A_{2} s^{2}+A_{1} s+A_{0}=0
$$

ここで,

$$
\begin{aligned}
& A_{0}=\omega_{h}^{2} \frac{K_{b}}{A_{c}^{\prime} \alpha_{a}}\left(\frac{1}{R_{d}-f^{\prime}\left(Q_{e}\right)}+\frac{1}{R_{b}}\right) \\
& A_{1}=\omega_{h}^{2}\left\{K_{b}\left(\frac{1}{R_{d}-f^{\prime}\left(Q_{e}\right)}+\frac{1}{R_{b}}\right)+\frac{1}{A_{c}^{\prime} \alpha_{a}}\right\} \\
& A_{2}=K_{b} K_{c}\left\{\frac{1}{R_{d}-f^{\prime}\left(Q_{e}\right)}\left(\frac{1}{R_{b}}+\frac{1}{R_{a}}\right)+\frac{1}{R_{b} R_{a}}\right\}+\omega_{h}^{2} \\
& A_{3}=K_{b}\left(\frac{1}{R_{d}-f^{\prime}\left(Q_{e}\right)}+\frac{1}{R_{b}}\right)+K_{c}\left(\frac{1}{R_{b}}+\frac{1}{R_{a}}\right) \\
& m_{a}^{\prime}=m_{h}+m_{s}, A_{c}^{\prime}=A_{c}+A_{s}
\end{aligned}
$$$$
\text { クッション室入口部絞り（以下, フィードホールと称 }
$$
する) の部分の変動圧力, 変動流量の関係式 (8), (9) において, $R_{b}=0\left(P_{b e}=P_{c e}\right)$ とすると (14) 式はバッ グ室とクッション室を合わせた単一プレナム系の振動数
方程式に, $K_{b} \rightarrow \infty$ (バッグ室容積 $V_{b e} \rightarrow 0$ ) とすると, クッション室のみをプレナムとする系の振動数方程式に それぞれ一致する。

Hurwitz の方法によれば，振動数方程式の係数がす べて正の場合, 振動系の安定条件は次式を満す場合であ る。

$$
A_{1} A_{2} A_{3}>A_{1}^{2}+A_{0} A_{3}^{2}
$$

計算に用いたモデル諎元 ${ }^{5)}$ を Table 1 に, 計算結果を Fig. 2〜4 亿示す。

Fig. 2 艇体振動の安定領域に及ぼすフィードホー ル絞りの影響

Fig. 3 ファン特性の影響

Fig. 4 バッグ室空気圧とクッション圧の関係

\begin{tabular}{|c|c|c|}
\hline & Calculation & Experiment \\
\hline Hull Weight & & $396.5 \mathrm{~kg}$ \\
\hline Seal Weight & & $66.0 \mathrm{~kg}$ \\
\hline Cushion Diameter (D) & $2.0 \mathrm{~m}$ & \\
\hline Cushion Area & $3.14 \quad \mathrm{~m}^{2}$ & $3.00 \mathrm{~m}^{2}$ \\
\hline $\begin{array}{c}\text { Projected Area }\left(A_{s}\right) \\
\text { of Seal }\end{array}$ & $0.628 \mathrm{~m}^{2}$ & $4.90 \mathrm{~m}^{2}$ \\
\hline Bag Volume & $1.57 \mathrm{~m}^{3}$ & $3.63 \mathrm{~m}^{3}$ \\
\hline Cushion Volume $\left(V_{c}\right)$ & $3.14 \mathrm{~m}^{3}$ & $1.76 \mathrm{~m}^{3}$ \\
\hline
\end{tabular}

因より，次のことが分かる。

1）Fig. 2 飞おいて, 安定境界の曲線は 2 次曲線で, その下方, 即ち低クッション压側が安定域となる。ファ ン特性曲線の傾き $f^{\prime}\left(Q_{e}\right)=0$ の場合, フィードホール を開くと安定域は広がり, 絞ると $f^{\prime}\left(Q_{e}\right)=-\infty$ の曲線

Table 1 Principal dimensions of ACV model 


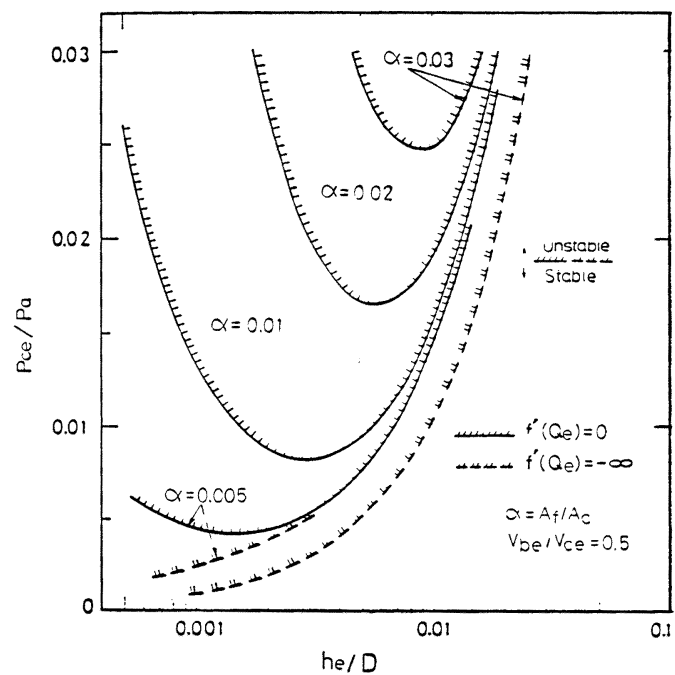

Fig. 2 Dynamic stability boundaries of heave motion

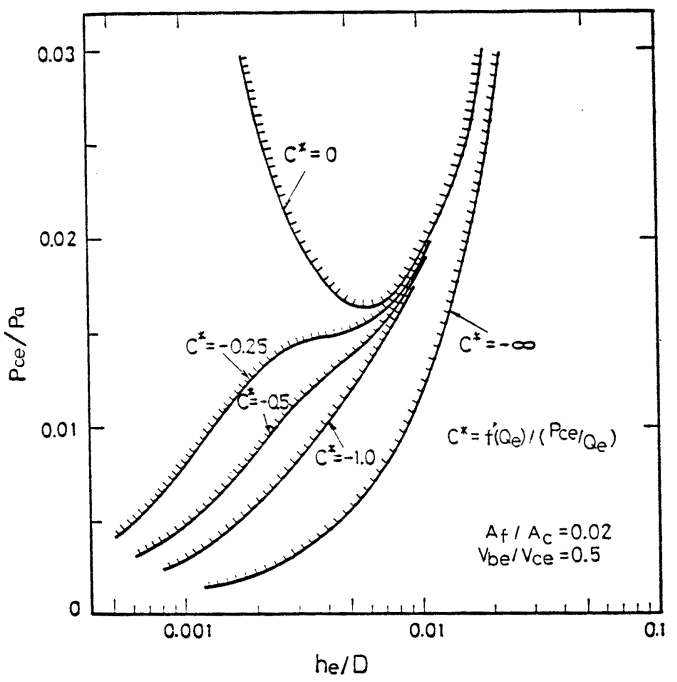

Fig. 3 Dynamic stability boundaries of heave motion

に漸近し，安定域は狭くなる。

2) Fig. 3 飞招いて, ファン特性曲線の傾き $f^{\prime}\left(Q_{e}\right)$ $\rightarrow 0\left(c^{*} \rightarrow 0\right)$ とすると安定域は広がる。フィードホー ルを開く場合の傾向に一致する。

3） Fig. 4 亿打いて, 安定境界線は下に凸の双曲線状 である。高クッション圧側の安定域は狭く, 低クッショ ン圧側の安定域の方が広い。フィードホール開度を大き くすると低クッション圧側の安定域が広がる。

(15) 式の判別式は, $R_{b}=0, \infty$ の極限では, 次のよう になる。

$$
R_{b} \rightarrow \infty
$$

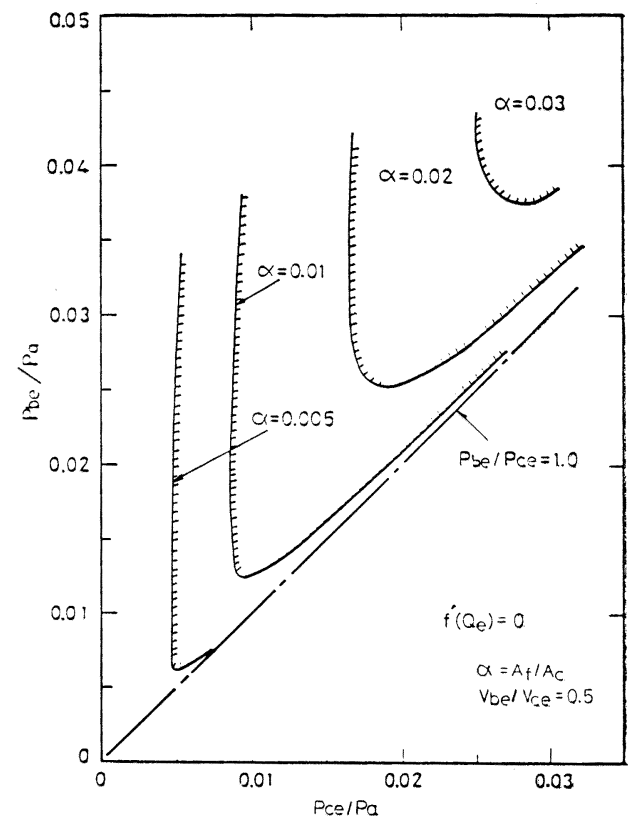

Fig. 4 Dynamic stability boundaries of heave mation

$$
\frac{K_{c}}{R_{a}}>\frac{1}{A_{c}{ }^{\prime} \alpha_{a}}
$$

$R_{b} \rightarrow 0$

$$
\begin{gathered}
K_{c} *\left(\frac{1}{R_{d}-f^{\prime}\left(Q_{e}\right)}+\frac{1}{R_{a}}\right)>\frac{1}{A_{c}^{\prime} \alpha_{a}} \\
K_{c} *=K_{b} K_{c} /\left(K_{b}+K_{c}\right)
\end{gathered}
$$

広いクッション面積 (低圧側) を持つ振動系は, 安定化 の傾向になる。 $K_{c} *$ は, バッグ室とクッション室を合わ せた単一プレナムに対して得られるパラメータである。 $\left(R_{d}-f^{\prime}\left(Q_{e}\right)\right) \rightarrow \infty$ とすれば, (16) 式と（17）式の差 は $K_{c}$ と $K_{c} *$ の違いのみで, 形式的には一致する。

Fig. 2, 3 において, $R_{b} \rightarrow \infty$ もしくは $\left(R_{d}-f^{\prime}\left(Q_{e}\right)\right)$ $\rightarrow \infty$ の場合にともに安定域が狭める傾向となったのは 式よりも理解できる。(15) 式の判別式は, $y_{h}=y_{s}$ 即ち シールの変形を無視している。シール変形によって, $K_{c} *$ の低娍度が大きいと， $R_{b} \rightarrow 0$ でも安定域を狭める 可能性がある。

\section{2 シール振動の安定領域}

$y_{h}=0$ としたシール振動系の振動数方程式からも, 同 型式の判別式を得ることができる。（14）式に相当する 振動数方程式の係数を $B_{0} \sim B_{3}$ と表わすと, 次のように なる。

$$
s^{4}+B_{3} s^{3}+B_{2} s^{2}+B_{1} s+B_{0}=0
$$

ここで,

$$
B_{0}=\omega_{c}^{2} \frac{K_{b}}{A_{s} \alpha_{a}} \frac{1}{R_{d}-f^{\prime}\left(Q_{e}\right)}
$$




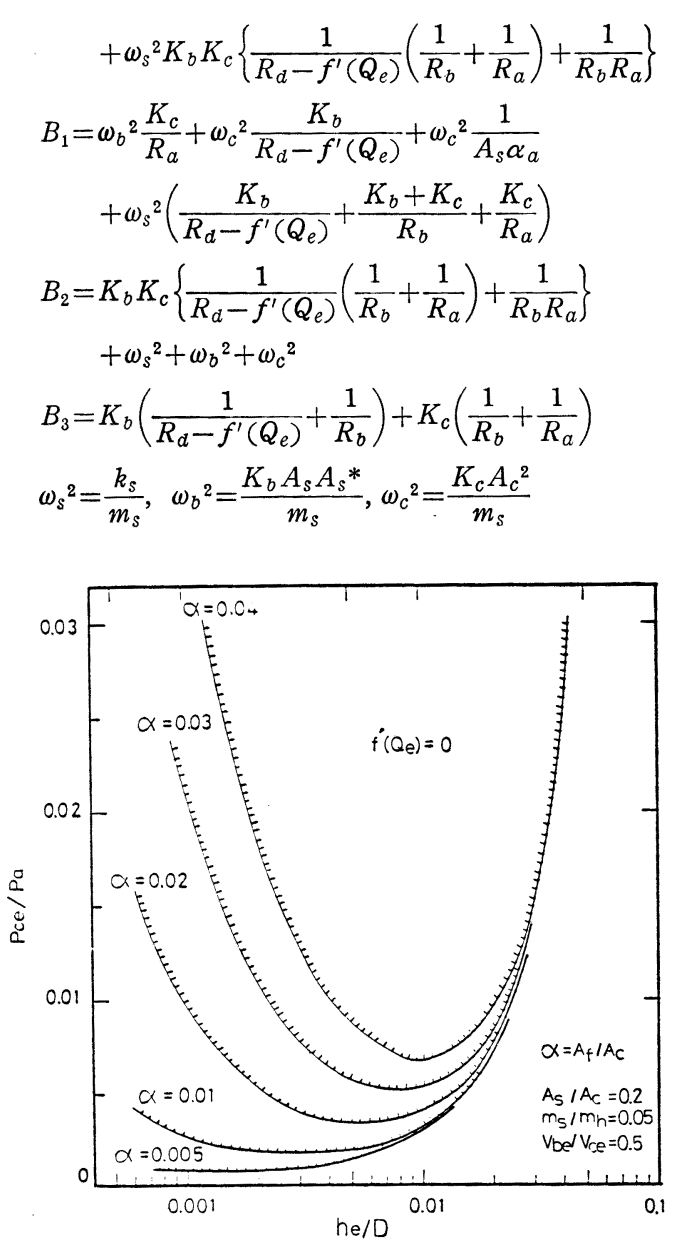

Fig. 5 Dynamic stability boundaries of seal vibration

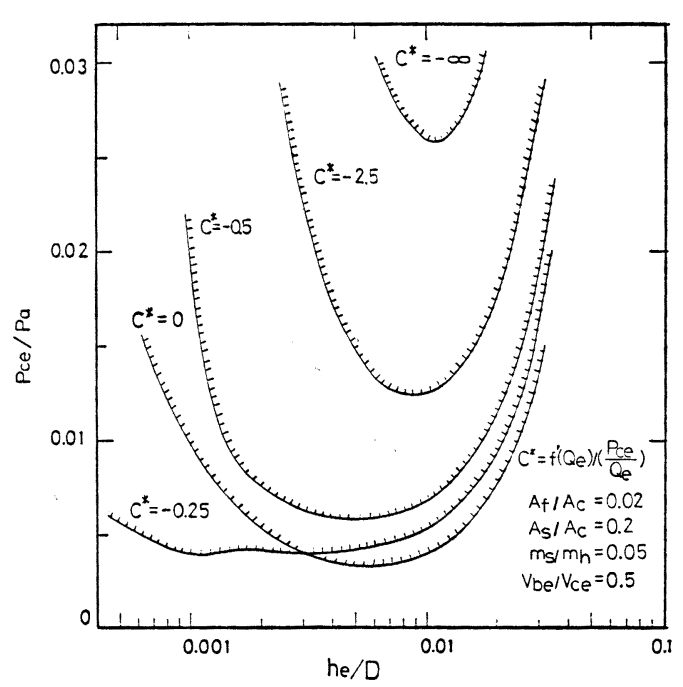

Fig. 6 Dynamic stability boundaries of seal vibration
艇体振動系の場合之同様に, Table 1 の艇形状や圧力, 流量特性に関して安定領域を数值計算する。シール特性 のパラメータは次のように設定した。

$$
\left.\begin{array}{l}
m_{s}=m_{h} / 20, \quad k_{s}=\left(2 \pi f_{s}\right)^{2} m_{s} \\
f_{s}=5 \mathrm{~Hz}, \quad A_{s}=0.2 A_{c}
\end{array}\right\}
$$

計算結果を以下に示す。

Fig. 5 シール振動の安定領域

$$
\text { 一フィードホール開度の影響—— }
$$

Fig. 6 ファン特性の影響

Fig. 7 バッグ室圧力とクッション室圧力の関係 図より，次のことが分る。

1）Fig. 5 に执いて,フィードホール開度を大きくす ると安定域は広がる。

2） Fig. 6 に打いて，全般にファン特性曲線の傾きを $f^{\prime}\left(Q_{e}\right) \rightarrow-\infty$ とする方が安定域が広がる。これは艇体 振動の場合とは逆傾向である。また，シール下端クリア ランスの小さい領域では, 安定曲線は特性曲線の傾きが 急になるにつれて一度狭くなり，再び広がる傾向を示 寸。

3）Fig. 7 亿沶いて, 安定領域の曲線は 2 次曲線状と なる。曲線の下側領域は安定域で，フィードホール開度 を大きくすると極小点は高圧側に移行し，安定域は広が る。

艇体振動の場合と同様に, 安定判別式の傾向を調べ る。 $\left(R_{d}-f^{\prime}\left(Q_{e}\right)\right) \rightarrow \infty$ の場合の安定判別式は,

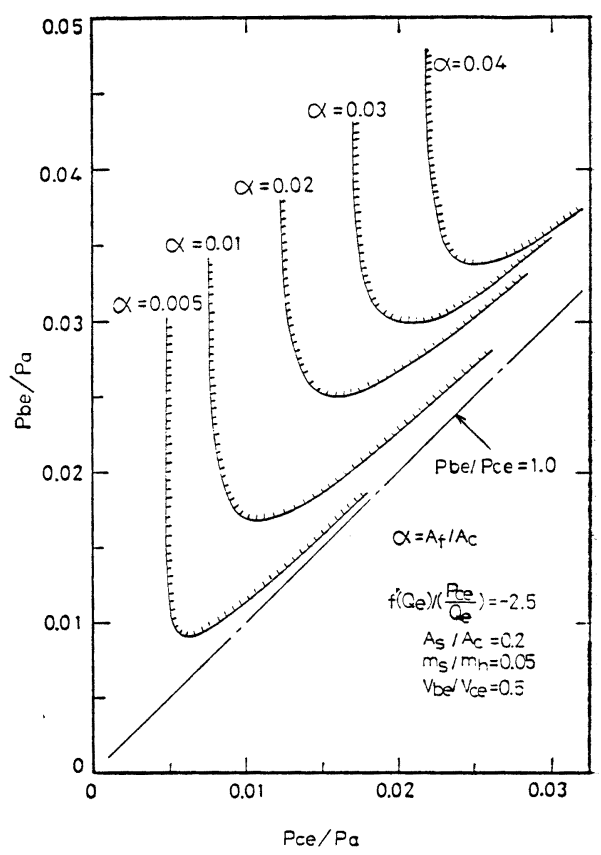

Fig. 7 Dynamic stability boundaries of seal vibration 


$$
\begin{gathered}
C_{1}{ }^{2} C_{3}\left(\frac{\omega_{s}}{\omega_{c}}\right)^{2}+C_{2}\left(\frac{\omega_{b}}{\omega_{c}}\right)^{2}+C_{1}\left(1+\frac{K_{b} K_{c}}{R_{a} R_{b}} \cdot \frac{1}{\omega_{c}^{2}}\right) \\
>C_{1}\left(\frac{\omega_{s}}{\omega_{c}}\right)^{2}+\frac{1}{A_{s} \alpha_{a}}
\end{gathered}
$$

ここで,

$$
\begin{aligned}
& C_{1}=\left(K_{b}+K_{c}\right) / R_{b}+K_{c} / R_{a}, C_{2}=\left(K_{b}+K_{c}\right) / R_{b} \\
& C_{3}=\frac{\left(\frac{\omega_{b}}{\omega_{c}}\right)^{2}+1}{\frac{K_{c}}{R_{a}}\left(\frac{\omega_{b}}{\omega_{c}}\right)^{2}+\frac{1}{A_{s} \alpha_{a}}}
\end{aligned}
$$

(20) 式より, $R_{b} \rightarrow 0$ の場合は $C_{1}{ }^{2}$ 項が大きくなり, 系は安定化する。 $R_{a}, R_{b}, \alpha_{a} \rightarrow \infty$ の場合, (20) 式は (21) 式のようになる。

$$
C_{1}\left(C_{1} C_{3}-1\right)\left(\frac{\omega_{s}}{\omega_{c}}\right)^{2}+C_{2}\left(\frac{\omega_{b}}{\omega_{c}}\right)^{2}+C_{1}>\frac{1}{A_{s} \alpha_{a}}
$$

（21）式によれば， $\left(\omega_{b} / \omega_{c}\right)$ が大きくなる場合，あるい は， $\left(C_{1} C_{3}-1\right)>0$ の条件下で $\left(\omega_{b} / \omega_{c}\right),\left(\omega_{s} / \omega_{c}\right)$ が大き くなる場合に系は安定化する。

$\left(R_{d}-f^{\prime}\left(Q_{e}\right)\right) \rightarrow 0$ の極限に対して, 安定判別式を求 める。

$$
K_{c}\left(\frac{1}{R_{b}}+\frac{1}{R_{a}}\right)>\frac{1}{A_{s} \alpha_{a}}
$$

（22）式では， $R_{b} \rightarrow \infty$ の時は（16）式と安定判別式は 同型式となる。安定化のためにはクッション室のパラメ 一タのみが関与する。 $R_{b} \rightarrow 0$ の場合は，安定化する傾 向となる。 $\left(R_{d}-f^{\prime}\left(Q_{e}\right)\right) \rightarrow 0, \infty$ のいずれの場合でる, $R_{b} \rightarrow 0$ は安定化傾向となることが分る。これらの傾向 は, Fig. 5〜7 の数值計算結果と一致する。

$\omega_{s}$ や $\omega_{b}$ の值を高くすることは，シール構造形態に よって変えることができる。 $\omega_{b}$ は $K_{b} A_{s}{ }^{2}(1+\beta)$ に比 例して高くなるため， $K_{b}$ が大きく， $(1+\beta)$ も大きい 時は相乗的に高くなる。

$K_{b}$ を大きくするのは, バッグ圧を 高めることや，バッグ室体積 $V_{b}$ を小 さくしても実現できる。 $\omega_{s}$ を高めるの は, アンティバウンス・ウォール1),6) の支柱効果によって上下振動に対する ばね定数を高めることが有効と言兄 る。

ダクトの動特性を含めると安定領域 の傾向はかなり複雑となる。また振動 系は，固有振動モードのいずれの一つ でも負隇衰となれば発振するため，連 成振動系としての安定化を検討する必 要がある。

\section{5 モ デル実験}

ここに示すモデル実験は別目的のた めの装置を流用しているため, エアク

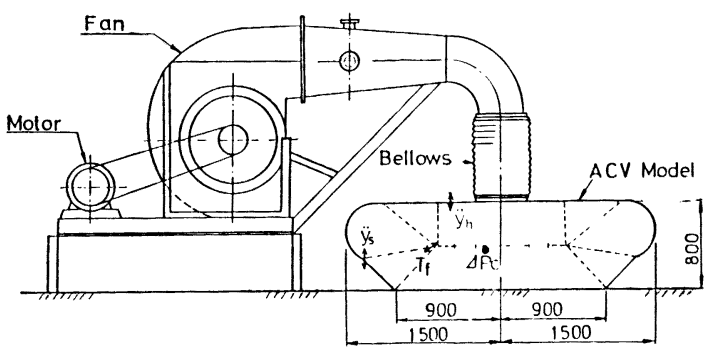

Fig. 8 Experimental model

ッション艇の一般的考察には十分ではないが, 解析手法 の確認の意味で引用する。

\section{1 実験方法および結果}

装置は, ファン, ダクト，模型本体で構成されてい る。概略を Fig. 8，主要目を Table 1 に示す。

ファンは，片吸込型ターボファンである。モーター回 転数は一定であり, ファン供給風量は, 空気吸込口のダ ンパー開度によって調節できる。ダクトは, レデューサ 一, ベント，ベローズの 3 部分に分けられる。ベント部 分の内部には，空気流を整流するためのガイドベーンを 取りつけてある。模型本体の上下動を拘束しないように ベローズを用いて接合した。

実験に使用した模型は, 圧力室型ホーバークラフトの 模型である。模型は, 艇体の平面形状が正方形で, 全周 にフレキシブルシールを付した压力室型エアクッション 艇である。圧力室は, 開口を持つ仕切り板によってバッ グ室とクッション室に仕切ってある。シール様式はバッ グ・フィンガータイプである。

実験は, ファンの吸込口のダンパー開度と異なるフィ ードホール開度の仕切り板 $\left(A_{f} / A_{c}=0.02 \sim 0.10\right)$ に取
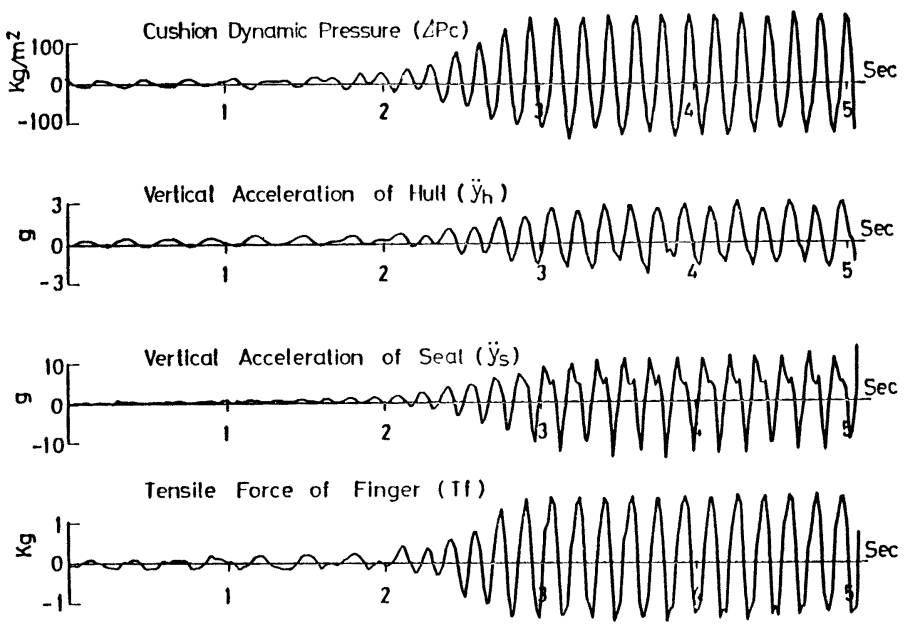

Fig. 9 Measured time history 


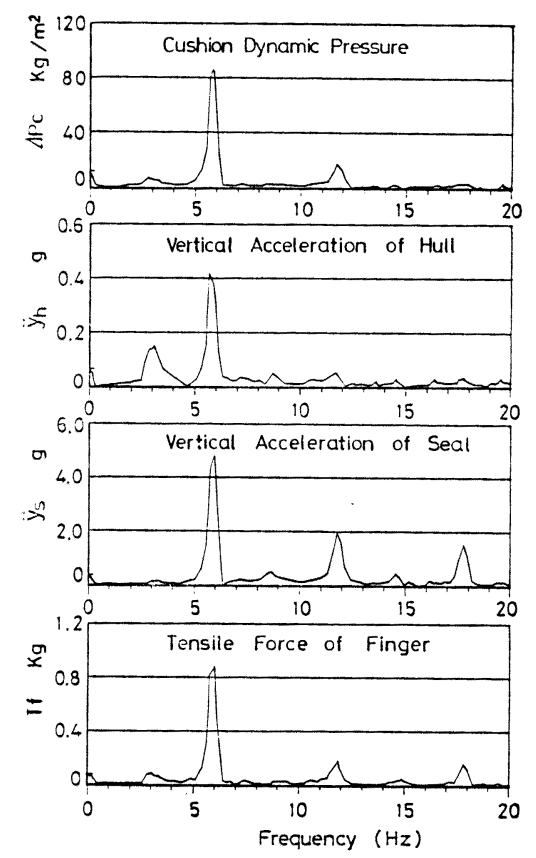

Fig. 10 Results of frequency analysis

Table 2 Test results of ACV model

\begin{tabular}{|c|c|c|c|c|c|c|}
\hline \multicolumn{2}{|l|}{$A_{f} / A_{c}$} & 0.02 & 0.04 & 0.06 & 0.08 & 0.10 \\
\hline \multicolumn{2}{|l|}{$P_{b e} / P_{c e}$} & 2.92 & 2.30 & 1.75 & 1.58 & 1.28 \\
\hline \multicolumn{2}{|c|}{ Stability } & $x$ & $\Delta$ & $\Delta$ & $x$ & $x$ \\
\hline \multirow{2}{*}{$\begin{array}{c}\begin{array}{c}\text { Peak } \\
\text { Frequency } \\
\mathrm{Hz}\end{array} \\
\end{array}$} & +1 & 3.0 & 2.8 & 3.0 & 2.5 & 2.3 \\
\hline & 12 & 7.4 & 6.6 & 6.0 & 5.4 & 4.4 \\
\hline
\end{tabular}

り換えて浮上テストし，安定性を確認した。自励振動を 生じたケースについては, 加速度, 圧力およびフィンガ 一取付部張力の変動を記録した。実験結果を以下の図表 に示す。結果は，いずれもファン吸込ロダンパー開度 $10^{\circ}$ のものである。

Fig. 9 時刻歷の計測波形 $\left(A_{f} / A_{c}=0.06\right)$

Fig. 10 周波数分析結果 $\left(A_{f} / A_{c}=0.06\right)$

Table 2 動的安定性㧍よび固有振動数の実測結果

Fig. 9, 10 および Table 2 に示すように, フィードホ 一ル開度 $A_{f} / A_{c}=0.04,0.06$ の場合を除き自励的な振 動の成長がみられた。ほぼ, 浮上とともに発振したもの を表中に×印で示している。 $A_{f} / A_{c}=0.04,0.06$ の場 合は，振動の成長する時もあったが，安定状態も見られ

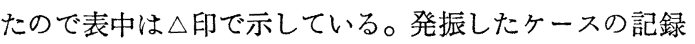
波形は, 振動が成長しやがてりミットサイクルを描くも のであった。ファン吸达ロダンパー開度を絞った場合に は十分に安定する領域が見られた。

記録波形に対するオーバーオールの周波数分析結果に は, 多数のピークが見られた。それらには，波形が非正
弦的なために倍調波成分も含まれているものと考えて， 最初のピークを一次 $\left(f_{1}\right)$, 引き続き漸減するように続 くピークを除きあらためて卓越するピーク周波数を 2 次 振動数 $\left(f_{2}\right)$ として読み取り表中に示した。 $f_{1}, f_{2}$ とも にフィードホール開度 $A_{f} / A_{c}$ の増加とともに単調に減 少している。

\section{2 数値計算結果および実験との比較}

実験条件に対する（13）式の運動方程式を解いて得ら れた固有振動の計算結果を以下の図に示す。

Fig. 11 固有振動特性とフィードホール開度の関係

Fig. 12 固有振動特性とシール形状係数 $(\beta)$ の関係 実験模型のシール形状はバッグ部が艇端縁より張り出 し，投影受纴面積が全クッション面積に対してかなり大
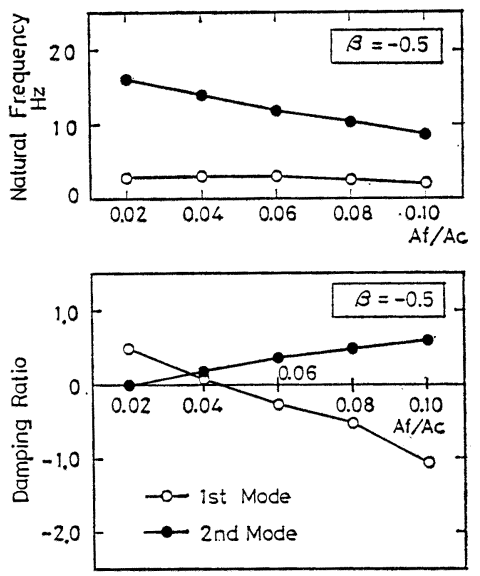

Fig. 11 Effect of feedhole area on natural vibration characteristics
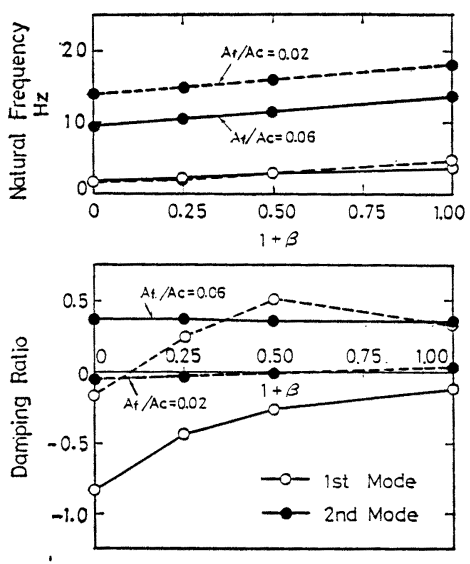

Fig. 12 Effect of seal geometrical factor $(\beta)$ on natural vibration characteristics 
きい割合を占める形態である。そのために，計算モデル のように水平自由度を拘束し鉛直自由度のみの 1 自由度 系に置き換えることには無理があるが，傾向の比較が目 的であるために次のようにシールのパラメータを設定し て適用した。その他の值は，Table 1 の值を用いた。

$m_{s}:$ シール総質量の約 $60 \%$

残質量は, 艇質量に加算

$k_{s}:$ 半円弧膜より導出されるばね定数

$A_{s}:$ 投影シール面積の約 $50 \%$

Fig. 11 のフィードホール開度 $\left(A_{f} / A_{c}\right)$ を変数とす る計算結果に拈いて, 固有振動数は 1 次, 2 次ともに $A_{f} / A_{c}$ の増加につれて減少している。位相より判断し て1次がヒービング振動，2次がシール振動モードと考 えられる。減衰比は, 1 次モードが単調減少, 2 次モー ドの值が増加する傾向を示した。 $A_{f} / A_{c}$ が $0.03 \sim 0.04$ に打いて 1 次， 2 次振動の減衰比が共に正となってい る。

Fig. 12 のシール形状係数 $(\beta)$ を変数とする計算結果 に打いて, 固有振動数は $\beta$ の増加につれて単調に增加す る。減衰比に関しては，1次と 2 次モードでは $\beta$ に対す る变化傾向を異にする。1次モードの減衰比は， $\beta$ の小 さい範囲では急增加するが， $\beta$ 大きくなるにつれて， $A_{f} / A_{c}$ の值によって飽和またはピークを持つ傾向とな る。2 次モードの減衰比は，及に対する変化は単調であ り微量である。またフィードホール開度 $A_{f} / A_{c}$ によっ て增減傾向が逆仙なている。

シールの変形容易さを表わすパラメータと考えられる シールの形状俰数 $\beta$ の影響が， 1 次モードに顕著に現わ れ，2次モードに微量であった点は, 実駼模型のシール 受圧面積の大きさおよびバッグ室体積の大きさによるも のと考壳られる。計算結果に上れば，ほぼ $\beta>-0.5$, $A_{f} \mid A_{c}<0.02$ を実現できれば， 1,2 次振動モード共に 正滅衰となる。

実験結果と比較してみる。 $\beta=-0.5$ の 1 次固有振動 数は, 実測の 1 次振動数 $f_{1}$ に近く, $A_{f} / A_{c}$ の增加に つれて減少する傾向も一致している。2次振動数の計算 值は, 実測の振動数 $\left(f_{2}\right)$ の約 2 倍高めである。安定性 に関しては， $A_{f} / A_{c}$ の中間域に準安定の領域のあるこ とは実験でも観察された。

\section{6 結言}

エアクッション艇の振動特性に関する基礎的研究を, 空気シール構造の挙動の観点より検討した。まず，エア クッション艇の運動方程式を, シール振動を含む線形化 モデルとして導出し，負性抵抗系としての動的安定特性 に及ぼすパラメータを調べるとともに，基礎的モデル実 験結果との比較も行った。それらの結果より次のような
ことが判明した。

1） シール振動の安定特性には, 送風路つ抵抗, 容量 およびシール形状特性が関係する。安定化のためのパラ メータの改良方向を図拉よび簡略化した判別式で示し た。

2）モデル実験では，ファン吸込口開度や圧力室内フ ィードホール開度のある值の範囲で, シール構造部の卓 越するタイプの自励振動を生じた。

3）圧力室内フィードホール開度を变えた実験におい て, 開度の増加とともにヒービング振動やシール振動の 固有振動数が減少することや開度とともに安定領域が变 わる傾向は, 数值計算結果と一致する。

本報告は，基礎的検討段階の成果であるが，定量的評 価には今後次のような検討が必要と考えられる。

1）シール形状を反映した計算（自由度を增したモデ ル化，パラメータ等価量推定精度の向上）

2) 非線形要素を含めた計算（パラメータの振幅依存 性，係数励振機構之の相互作用)

3）実験精度の向上（空気漏洩量など測定量の充実, 模型精度・パラメータ可変範囲の拡大等）

最後に，本論文をまとめるのに際して有益な御助言を 頂いた元良誠三東大名誉教授並びに防衛庁技術研究本部. 第 1 研究所村上俊一博士に心から謝意を表します。

\section{参 考 文 献}

1) P. J. Mantle : Air Cushion Craft Development. David W Taylor Naval Ship Research and Development Center Report. DTNSRDC-80/ $012,80$.

2) W. A. Crago: Problems Associated with the Use of Skirts on Hovercraft, Proceedings. Institution of Mechanical Engineers. Vol.182, Part 2A，1967 1968.

3）藤井澄二：振動弁迀流体柱の励振（第 3 報）, 日本機栈学会論文集, 21 巻, 105 号, 1952.

4) L. M. Sweet, H. H. Richardson, D. N. Wormley: Linearized Models, Stability Criteria and Experimental Verification for Plenum Air Cushions with Compressor Duct Interactions, MIT, Department of Mechanical Engineering Report DOT FR 10007.

5) M. J. Hinchey, P. A. Sullivan : Duct Effects on the Heave Stability of Plenum Air Cushions, Journal of Sound and Vibration 60 (1), 87 99, 1978.

6) R. L. Wheeler : Hover Craft Skirts, 1 st International Hovering Craft Hydrofoil and Advanced Ttansit System Conference, May, 1974. 